\author{
Agnieszka Sawińska \\ https://orcid.org/0000-0001-9745-3628 \\ Uniwersytet Szczeciński \\ Katedra Zarządzania Turystyką \\ Zakład Gospodarki Turystycznej i Uzdrowiskowej \\ agnieszka.sawinska@usz.edu.pl
}

\title{
KSZTAŁTOWANIE PRZESTRZENI REKREACYJNEJ SZCZECINA W DZIAŁANIACH PODEJMOWANYCH PRZEZ WŁADZE MIASTA
}

\begin{abstract}
Abstrakt: Artykuł ma charakter empiryczny i prezentuje część badań prowadzonych w latach 2012-2017 w ramach projektu badawczego „Aktywność turystyczna i rekreacyjna mieszkańców na przykładzie Szczecina”. Rozważania stanowią ocenę działań podejmowanych przez władze miasta w zakresie kształtowania przestrzeni rekreacyjnej miasta, w kontekście zdiagnozowanych potrzeb i uwarunkowań. Przeprowadzone analizy wykazały, że wydatki miasta władz związane z kulturą fizyczna, turystyką i rekreacją systematycznie rosną, co wiąże się z podejmowaniem nowych projektów w zakresie rozwoju rekreacji. Świadczy to o dużym znaczeniu rekreacyjnego zagospodarowania miasta dla kompleksowo rozumianej jakości życia w mieście. Dodatkowym aspektem prowadzonych inwestycji w Szczecinie jest zmiana orientacji przestrzennej miasta i przywrócenie obszarom nadrzecznym ich rekreacyjnej funkcji. Ponadto stwierdzono, że prowadzone działania i projekty pozostają w ścisłej korelacji ze zdiagnozowanymi oczekiwaniami mieszkańców i turystów.
\end{abstract}

Słowa kluczowe: miasto, przestrzeń rekreacyjna, jakość życia, polityka miast, Szczecin.

\section{SHAPING THE RECREATIONAL SPACE OF SZCZECIN IN THE ACTIVITIES UNDERTAKEN BY THE CITY AUTHORITIES}

Abstract: The article is empirical and presents part of the research conducted in 2012-2017, as a part of the research project "Tourist and recreational activity of residents on the example of Szczecin". The considerations are an assessment of the activities undertaken by the local authorities in the area of shaping the recreational space of the city in the context of diagnosed needs and conditions. The analyzes showed that the number of projects undertaken in the field of recreation development is systematically growing. This demonstrates the great importance of recreational urban development for the comprehensive quality of life in the city. An additional aspect of the investments carried out in Szczecin is the change of the city's spatial orientation and restoration of its recreational function to the riverside areas. It was also found out that the activities and projects carried out are closely correlated with the diagnosed expectations of residents and tourists.

Keywords: city, recreational space, quality of life, local policy, Szczecin.

\section{WSTĘP}

Współczesne miasta pełnią liczne funkcje, których rozwój wpływa na przemiany $w$ ich przestrzeni. Jedną z funkcji, która w ostatnich latach nabiera szczególnego znaczenia jest funkcja rekreacyjna miast, co wiąże się z tym, że rekreację coraz częściej postrzega się jako istotny element wpływający na jakość życia mieszkańców. Z kolei poprawa jakości życia mieszkańców stanowi główny wyznacznik rozwoju miast i jest uwzględniana w strategiach i działaniach jednostek samorządu terytorialnego. Przemiany w przestrzeni rekreacyjnej miast powinny wiązać się z identyfikacją potrzeb mieszkańców oraz z wykorzystaniem potencjału endogenicznego miasta. W tym celu wydaje się uzasadniona identyfikacja głównych uwarunkowań aktywności rekreacyjnej mieszkańców, określenie preferowanych przez nich form aktywności rekreacyjnej oraz analiza podaży rekreacyjnej.

Widząc taką potrzebę pracownicy Zakładu Gospodarki Turystycznej i Uzdrowiskowej Katedry Zarządzania Turystyką Uniwersytetu Szczecińskiego przeprowadzili w latach 2012-2017 badania w tym zakresie. Niniejszy artykuł stanowi ich podsumowanie i ma głównie charakter empiryczny. Szczególną uwagę zwrócono na ocenę działań podejmowanych przez władze miasta w odniesieniu do kształtowania rekreacyjnej przestrzeni publicznej. Należy podkreślić, że przedstawione w opracowaniu wyniki stanowią jedynie część tych badań i prezentują aspekty związane z rekreacją 
i polityką miasta w tym zakresie. Część praktyczna artykułu poprzedzona jest krótkim przeglądem literatury dotyczącym przestrzeni rekreacyjnej miast.

\section{PRZESTRZEŃ REKREACYJNA MIAST - ROZWAŻANIA TEORETYCZNE}

Interdyscyplinarność i wielowymiarowość przestrzeni rekreacyjnej pozwala na podejmowanie rozważań $\mathrm{i}$ analiz z różnych punktów widzenia. Koncentrując się na podejściu społeczno-ekonomicznym należy mieć na uwadze aspekty dotyczące geografii, ekonomii, socjologii.

Jak stwierdził Liszewski (2014), wyznacznikiem przestrzeni miejskiej jest jej organizacja, pozarolnicza funkcja ekonomiczna, status prawny i „społeczność miejska", czyli cechy organizacyjne, funkcjonalne i społeczne. Z kolei Włodarczyk (2011) w przestrzeni miasta wyróżnił m.in. przestrzeń czasu wolnego, a więc taka, w której mają miejsce wszelkie formy aktywności związane z zagospodarowaniem czasu wolnego, z wyłączeniem tzw. przestrzeni „domowej”, czyli miejsca stałego zamieszkania (konkretny adres). Może to być zarówno aktywność podejmowana przez turystów, jak i mieszkańców. Ponadto w przestrzeni czasu wolnego mogą mieć miejsce różne rodzaje aktywności podejmowanej okazjonalnie (np. zwiedzanie muzeum, spacer szlakiem turystycznym) czy zachowania rutynowe (np. wyjście do kina, restauracji, na basen). Przestrzeń tę często dzieli się na przestrzeń rekreacyjną i przestrzeń turystyczną, co jest uzasadnione m.in. względami marketingowymi. Może to wiązać się również z działaniami prowadzonymi w ramach marketingu terytorialnego miast, kiedy istotne staje się zidentyfikowanie i zaspokojenie potrzeb wielu grup interesariuszy (mieszkańców, turystów, przedsiębiorców, studentów czy inwestorów). W przypadku przestrzeni rekreacyjnej i turystycznej potrzeby te niejednokrotnie są zbliżone czy tożsame, a ich zaspokojenie przyniesie korzyści wielu odbiorcom.

Jako przestrzeń rekreacyjną określa się zatem część przestrzeni geograficznej, na której pojawia się zjawisko rekreacji (fizycznej, towarzyskiej czy kulturalno-rozrywkowej). Również przestrzeń turystyczna (w której obserwowany jest ruch turystyczny) jest przestrzenią rekreacyjną (Mokras-Grabowska, 2017). Jak zaznaczają Faracik, Kurek, Mika i Pawlusiński (2015) w badaniach nad turystyką podkreśla się również rolę tzw. miejskiej turystyki rekreacyjnej. Autorzy zauważaja, że tradycyjna funkcja rekreacyjna przestrzeni miast miała wcześniej charakter endogeniczny i była wyraźnie ukierunkowana na mieszkańców oraz realizację ich potrzeb związanych z regeneracją sił fizycznych i psychicznych. Obecnie rekreacja w mieście ma także wymiar egzogeniczny, skierowana niejako „na zewnątrz” - do przyjezdnych. Egzogeniczną funkcję rekreacyjną miast można identyfikować poprzez różne formy aktywności osób przyjezdnych, takie jak np.: spacery, spotkania towarzyskie w obiektach gastronomicznych, uczestnictwo w wydarzeniach sportowych, zabawie i rozrywce, robienie zakupów dla przyjemności.

Liszewski (2014), analizując formy miejskiej przestrzeni turystycznej (która jest częścią rekreacyjnej przestrzeni miast), identyfikuje osiem grup tej przestrzeni. Są to: 1) obiekty kultu religijnego i cmentarze, 2) obiekty o charakterze rezydencjonalnym i kamienice, 3) budynki i budowle użyteczności publicznej, 4) tereny zielone (parki, ogrody i inne formy), 5) zabytki techniki, zakłady przemysłowe, 6) muzea, pomniki, fontanny i inne, 7) układy urbanistyczne (osiedla, ulice, place i inne obiekty, np. Wawel), 8) inne formy miejskiej przestrzeni turystycznej. Liczbę form w każdej grupie uznaje zaś za przejaw atrakcyjności miasta, a wielkość opisu każdej formy (grupy) za jej rangę w przestrzeni turystycznej.

Istotnymi elementami przestrzeni turystycznej miasta - jak wskazuje Włodarczyk (2011) - jest dziedzictwo przyrodnicze, dziedzictwo kulturowe, infrastruktura oraz człowiek, który nie tylko użytkuje tę przestrzeń, ale także organizuje i zarządza nią. W tym kontekście szczególną rolę należy przypisać samorządom terytorialnym i podmiotom odpowiedzialnym za kształtowanie przestrzeni rekreacyjnej miasta.

Przemianom w przestrzeni rekreacyjnej miast poświęca również uwagę Mokras-Grabowska (2017), która podkreśla dynamizm tych zmian oraz ewolucję charakteru podejmowanych działań kształtujących przestrzeń rekreacyjną miasta. Autorka zauważa, że do niedawna tworzenie terenów rekreacyjnych w mieście ograniczało się głównie do zakładania parków czy budowania boisk sportowych. Obecnie tereny rekreacyjne w miastach zyskują coraz bardziej różnorodną formę, gdyż ich twórcy nie skupiają się już tylko na ich aspekcie funkcjonalnym, ale biorą także pod uwagę względy estetyczne (ład przestrzenny i wygląd). Przebywanie w takiej przestrzeni ma wywoływać pozytywne doznania, przyciągać i intrygować (Bierwiaczonek, 2016). Jest to odpowiedź na zmieniające się oczekiwania uczestników rekreacji, rosnące znaczenie doświadczeń we współczesnej aktywności rekreacyjnej (turystycznej). Jak podaje Mokras-Grabowska (2017), powołując się na Wantuch-Matla (2016), przestrzeń miasta w XXI w. przestała być "płaska”, „dwuwymiarowa”. Powstają w niej nowatorskie projekty w postaci wertykalnych parków, tarasów rekreacyjnych, platform widokowych, kreatywnych placów zabaw, przystani dla łodzi, plaż na bulwarach nadrzecznych czy parków ponad ulicami, tworzonych na dawnych estakadach kolejowych.

Zmiany w przestrzeni rekreacyjnej miasta wpisują się w działania zmierzające do poprawy jakości życia mieszkańców. Wśród domen jakości życia wymienia 
się m.in. materialne warunki życia, aktywność ekonomiczną i warunki pracy, zdrowie, edukację, czas wolny i relacje społeczne, bezpieczeństwo ekonomiczne i fizyczne, państwo i podstawowe prawa, jakość środowiska i subiektywny dobrostan (Eurostat..., 2011). Rekreacja jest zatem dziedziną aktywności człowieka, która wywiera istotny wpływ naobiektywny i subiektywny wymiar życia, jeśli jego jakość będzie zależała od odczuwanego dobrobytu materialnego, społecznego, fizycznego i emocjonalnego (Śniadek, Zajadacz, 2014).

\section{POLITYKA WŁADZ MIASTA SZCZECINA W ZAKRESIE KSZTAŁTOWANIA PRZESTRZENI REKREACYJNEJ MIASTA W KONTEKŚCIE ZDIAGNOZOWANYCH POTRZEB I UWARUNKOWAŃ LOKALNYCH}

Przeprowadzona w 2017 r. ocena działań podejmowanych przez władze Szczecina w zakresie rozwoju turystyki i rekreacji oraz wskazanie możliwych kierunków rozwoju rynku usług rekreacyjnych w mieście stanowiło piąty, ostatni etap projektu badawczego pt. „Miasto jako obszar aktywności turystycznej i rekreacyjnej mieszkańców, na przykładzie Szczecina". Ocena ta poprzedzona była studiami literaturowymi, analizą podaży rekreacyjnej oraz badaniami aktywności rekreacyjnej mieszkańców miasta podejmowanej zarówno w Szczecinie, jak i podczas podróży turystycznych do innych miast.

Studia teoretyczne (etap I - 2012 r.) pozwoliły przyjąć założenie, że rozwój funkcji rekreacyjnej przyczynia się do rozwoju miast, poprzez poprawę jakości życia mieszkańców, aktywizację lokalnej gospodarki, poprawę wizerunku miasta oraz rewaloryzację przestrzeni miejskiej.

Podstawową konkluzją etapu II (przeprowadzonego w 2012 r.) było stwierdzenie, że podaż pierwotna wynikająca z zasobów środowiska przyrodniczego, ma w Szczecinie zdecydowanie dominujący charakter, determinując większą część aktywności rekreacyjnej mieszkańców. Uznano również, że ma duże znaczenie dla aktywności podejmowanej przez turystów, szczególnie $\mathrm{w}$ zakresie turystyki wodnej ${ }^{1}$. Analizy potwierdziły bardzo zróżnicowany charakter podaży wtórnej i różny stopień jej wykorzystywania przez mieszkańców i turystów. Za istotny element podaży turystycznej uznano obiekty i usługi o charakterze kulturowym i historycznym, z których korzystają nie tylko turyści, ale też mieszkańcy, podobnie jak z obiektów kulturalnych i rozrywkowych. Uzyskane na tym etapie wyniki wykazały również, że rozwinięta podaż dla rekreacji ruchowej jest w głównej mierze skierowana do mieszkańców.

Na etapie trzecim (2014), na podstawie badań ankietowych przeprowadzonych na grupie 390 osób, dokonano identyfikacji dominujących form rekreacji wybieranych przez mieszkańców Szczecina. Jak pokazały przeprowadzone badania najchętniej wybieraną formą aktywności spośród rekreacji czynnej jest rekreacja na świeżym powietrzu (jazda na rowerze, wędkarstwo, bieganie, spacery). Dominującą formą uprawianej rekreacji na świeżym powietrzu, wskazywanym przez respondentów, zarówno jako aktywność podejmowana kilka razy $w$ tygodniu, jak i kilka razy w miesiącu, są spacery. Na drugim miejscu plasowała się jazda na rowerze. Mieszkańcy Szczecina odnieśli się pozytywnie do dostępności komunikacyjnej do miejsc przeznaczonych do rekreacji na świeżym powietrzu, natomiast niżej ocenili czystość tych miejsc. W związku z tym stwierdzeniem wskazano, że istotne wydaje się stworzenie przez władze lokalne odpowiednich warunków materialno-technicznych do uprawiania rekreacji na świeżym powietrzu, poprzez rozbudowę ścieżek rowerowych, tworzenie miejsc do wypoczynku, ale także zadbanie o utrzymywanie w nich czystości. Ważną rolę ich zdaniem powinno odgrywać również dbanie o zieleń miejska, ze wskazaniem na park Kasprowicza, Jasne Błonia i Wały Chrobrego, jako kluczowe miejsca do uprawiania tej formy rekreacji, niezależnie od miejsca zamieszkania. Badania (Raport. Aktywność rekreacyjna..., 2014; Sawińska, 2016, 2018) pokazały też, że mieszkańcy Szczecina poszukują form ruchu najbardziej odpowiednich dla siebie ze względu na dostępność oraz koszty. Najchętniej wybierali wobec tego te propozycje, które pozwalają im na rekreację w pobliżu miejsca zamieszkania.

Z kolei z badań ankietowych przeprowadzonych w latach 2015 i 2016 wynika, że największą popularnością spośród miejsc do rekreacji ruchowej cieszą się miejskie szlaki turystyczne, szlaki rowerowe oraz stadiony, co wskazuje na zainteresowanie rekreacją na świeżym powietrzu. Wśród najbardziej atrakcyjnych miejsc w Szczecinie wybieranych zarówno przez turystów, jak i jego mieszkańców znajdują się Wały Chrobrego i park Kasprowicza. Turyści wskazywali też otoczenie Zamku Książąt Pomorskich i promenadę z widokiem na Odrę. Miejsca te należy uznać za wyróżnikowe walory miasta (Meyer, Gardzińska, Sawińska, 2016).

Kształtowanie publicznej i semipublicznej przestrzeni rekreacyjnej miasta wiąże się ściśle z przyjęciem odpowiedniej prorekreacyjnej polityki władz miasta, funkcjonowaniem podmiotów odpowiedzialnych za wyznaczanie i realizację działań na rzecz rozwoju rekreacji w mieście. Do 1 marca 2012 r. turystyka i rekreacja znajdowały się w zakresie kompetencji administracji Wydziału Sportu i Turystyki Urzędu Miasta Szczecina, 
później przydzielono je Biuru Komunikacji Społecznej i Marketingowej oraz Wydziałowi Sportu. Po likwidacji Biura Komunikacji Społecznej i Marketingu w 2016 r podzielono jego zadania w ten sposób, że strategia marki i biuro prasowe pozostało w Biurze Prezydenta, część turystyczna trafiła do Żeglugi Szczecińskiej. Turystyka. Wydarzenia Sp. z o.o., zaś część „,brandingowa” i promocyjna do Szczecińskiej Agencji Artystycznej (Biuletyn Urzędu Miasta Szczecin, 2017).

W podstawowych kompetencjach Żeglugi Szczecińskiej znalazły się administrowanie nabrzeżami stanowiącymi własność zarówno gminy miasto Szczecin, jak i samej Spółki, oraz zarządzanie szczecińskimi bulwarami, w tym m.in. utrzymanie czystości na terenie bulwarów, opieka nad Aleją Żeglarzy na bulwarze Piastowskim oraz nad punktami handlowo-usługowymi. Żegluga Szczecińska sprawuje również nadzór nad uznanymi za wyjątkowe zakątkami wodnymi. Są to miejsca rekreacyjne m.in. przeznaczone dla żeglarzy, kajakarzy, turystów czy ornitologów. W 2016 r. do jej zadań dołączyła również działalność „eventowa”, opierająca się na kompleksowej organizacji wydarzeń w przestrzeni miejskiej. Jednym z projektów realizowanych przez Spółkę jest Kolorowa Aleja. W jego ramach odbył się m.in. Jarmark Bożonarodzeniowy na trzech szczecińskich placach, podczas którego szczecinianie i turyści mogli poczuć niezwykły klimat świąt. W 2017 r. w przestrzeni Alei Kwiatowej miały miejsca wydarzenia takie, jak: Jarmark Wielkanocny, Miasto Ogród oraz drugi Jarmark Bożonarodzeniowy. Największą impreza, którą współorganizowała Spółka w 2017 r. był finał regat The Tall Ships Races (Żegluga Szczecińska..., 2017).

Kolejną jednostką zależną od władz miasta, ale pozostającą poza strukturami Urzędu Miasta, jest Szczecińska Agencja Artystyczna (Szczecińska Agencja Artystyczna, 2017). Jest to miejska instytucja kultury organizująca wydarzenia o charakterze kulturalnym, artystycznym i rozrywkowym. W dorobku ostatnich lat działalności SAA znajdują się m.in.:

- cykliczne imprezy masowe: Dni Morza - Sail Szczecin, Szczecińska Majówka, Miejski Sylwester, Finał Wielkiej Orkiestry Świątecznej Pomocy, Festiwal Młodych Talentów;

- cykliczne imprezy kulturalne: Różany Ogród Sztuki, Nagroda Literacka dla Autorki „Gryfia” przyznawana przez Kurier Szczeciński, Odkryj Książkę na Nowo, Szczecin Jazz, Zjazd Młodych Gwiazd, Nagroda Artystyczna Miasta Szczecin;

- koncerty artystów zagranicznych: Joe Cocker, Pat Metheny, Deep Purple, Bobby McFerrin, Emir Kusturica, Reamonn;

- oprawa artystyczna finału regat The Tall Ships Races (2013, 2017) oraz The Baltic Tall Ships Regatta (2015).

Z kolei przeprowadzona analiza dokumentów planistycznych, które mogą w istotny sposób wpłynąć na kształt podaży turystycznej i rekreacyjnej w Szczecinie, nie wykazała zapisów literalnie związanych z turystyką i rekreacją. Pozwoliła jednak na zidentyfikowanie w dokumentach strategicznych tych elementów, które podkreślają znaczenie turystyki i rekreacji dla rozwoju miasta. Głównym dokumentem strategicznym dla miasta Szczecin jest Strategia rozwoju Szczecina. 2025 (2011), która formułuje jedną z wizji miasta jako: „Szczecin - miasto o znacznych zasobach zieleni i wód, bezpieczne, przyjazne i atrakcyjne dla mieszkańców, inwestorów i turystów, oferujące bogatą ofertę kulturalną oraz wysoką jakość życia i wypoczynku". W tym miejscu warto zaznaczyć, że w Strategii... (2011) przewidywano opracowanie 12 programów (w tym „Program rozwoju turystyki") i 16 tzw. polityk w określonych dziedzinach, które mają stanowić bezpośrednie narzędzie realizacji zadań miasta. Zarówno planowany „Program rozwoju turystyki” oraz „Polityka kultury fizycznej, turystyki i rekreacji" do listopada $2017 \mathrm{r}$. nie powstały, aczkolwiek działania w zakresie turystyki i rekreacji znalazły się w przedstawionym przez Prezydenta Miasta Piotra Krzystka „Programie Szczecin 2020”, jak i w ,Wieloletnim programie rozwoju Szczecina" (WPRS), będącym integralną częścią Strategii rozwoju Szczecina. 2025 (2011) i stanowiącym zbiór projektów oraz zadań strategicznych dedykowanych poszczególnym celom strategicznym (Szczecin, 2017).

W „Programie Szczecin 2020” zwrócono uwagę na kwestię dotyczącą odpoczynku i rekreacji jako ważnego elementu otoczenia. Stwierdzono, że myśląc o przyszłości, nie można pominąc walorów przyrodniczych Szczecina. Jego położenie geograficzne, tj. lokalizacja na szlaku żeglugowym, w otoczeniu zieleni parków i puszczy to atuty miasta sprzyjające kreowaniu miejsc wypoczynku i rekreacji zarówno dla mieszkańców, jak i turystów. W odniesieniu do tych aspektów „Program Szczecin 2020" zawiera propozycje działań o charakterze bieżącym i inwestycyjnym, takich jak:

1. Turystyczny Szczecin - kontynuacja i rozwój realizowanego od 2012 r. programu kooperacji z lokalnymi touroperatorami, restauratorami, hotelami; wzbogacanie projektu o nowe przedsięwzięcia - projekt „Wodna brama Europy”, który zakłada rozwój turystki wodnej w oparciu o Port Jachtowy Szczecin i potencjał szlaków wodnych zachodniej Europy.

2. Produkty turystyczne - wyzwaniem dla Szczecina cały czas pozostaje tworzenie atrakcyjnych produktów turystycznych, dostępnych na co dzień, wypełniających przestrzeń pomiędzy spektakularnymi wydarzeniami, jak np. regaty The Tall Ships Races, Dni Morza czy Festiwal Ogni Sztucznych Pyromagic.

3. Ekozmiany - bardzo ważnym elementem Szczecina jest projekt „Szczecin Floating Garden 2050”, ukazujący miasto jako atrakcyjną do życia, nieprzytłaczającą metropolię, kładącą duży nacisk na ekologię. 


\begin{tabular}{|c|c|c|c|c|c|c|c|c|c|c|c|c|c|c|c|c|c|c|c|}
\hline & ○. & 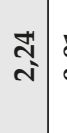 & $\begin{array}{l}\overline{0} \\
0 \\
0\end{array}$ & 1 & $\begin{array}{c}\text { స్ } \\
\text { క }\end{array}$ & $\begin{array}{l}0 \\
\stackrel{0}{0} \\
0\end{array}$ & š & 1 & $\mid \begin{array}{l}5 \\
0 \\
0\end{array}$ & : & $\begin{array}{l}-5 \\
0 \\
0\end{array}$ & 芯 & $\begin{array}{l}\stackrel{2}{0} \\
0 \\
0\end{array}$ & š & 1 & 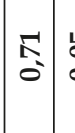 & $\begin{array}{l}0 \\
0 \\
0 \\
0\end{array}$ & $\stackrel{2}{\stackrel{2}{\sigma}}$ & 1 \\
\hline & $\frac{\text { డ్ }}{2}$ & 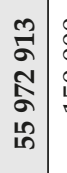 & $\begin{array}{l}8 \\
8 \\
0 \\
\stackrel{10}{-}\end{array}$ & 1 & \begin{tabular}{l}
8 \\
0 \\
0 \\
\multirow{1}{1}{} \\
1
\end{tabular} & $\begin{array}{l}8 \\
8 \\
o \\
+ \\
+ \\
\forall\end{array}$ & $\begin{array}{l}\text { సิ } \\
\text { \& } \\
\stackrel{9}{+}\end{array}$ & 1 & $\mid \begin{array}{l}8 \\
\vdots \\
0 \\
\overrightarrow{2}\end{array}$ & 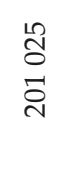 & 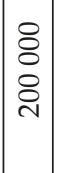 & $\begin{array}{l}8 \\
8 \\
\circ \\
8 \\
-1\end{array}$ & $\begin{array}{l}\stackrel{R}{ } \\
\infty \\
\vec{\Xi} \\
\underset{\sim}{\sim}\end{array}$ & $\begin{array}{l}\stackrel{8}{9} \\
\stackrel{9}{+} \\
\stackrel{1}{\infty} \\
\stackrel{5}{n}\end{array}$ & 1 & 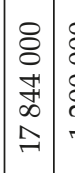 & 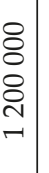 & 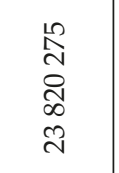 & 1 \\
\hline & $\therefore$ & 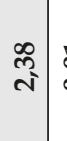 & $\begin{array}{l}5 \\
0 \\
0\end{array}$ & 1 & 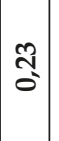 & $\frac{9}{0}$ & 1 & $\begin{array}{l}8 \\
\circ\end{array}$ & $\mid \begin{array}{l}0 \\
0 \\
0\end{array}$ & $\begin{array}{l}\sigma \\
0 \\
0\end{array}$ & $\begin{array}{l}\tilde{\sigma} \\
0 \\
0\end{array}$ & $\begin{array}{l}\text { D' } \\
\stackrel{-}{\circ}\end{array}$ & $\begin{array}{l}\text { 总 } \\
0\end{array}$ & $\begin{array}{l}\text { D' } \\
0\end{array}$ & 1 & $\begin{array}{l}: \\
:\end{array}$ & $\begin{array}{l}\mathbf{0} \\
\vdots \\
0\end{array}$ & $\underset{\approx}{\approx}$ & $\stackrel{8}{\circ}$ \\
\hline & 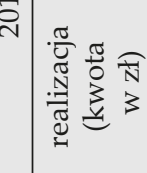 & 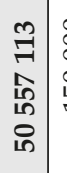 & $\begin{array}{l}8 \\
8 \\
\circ \\
\stackrel{1}{\circ}\end{array}$ & 1 & 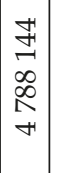 & $\begin{array}{l}\hat{⿵} \\
\hat{n} \\
\sigma \\
\sigma \\
\text { nે }\end{array}$ & 1 & $\begin{array}{l}\infty \\
0 \\
= \\
=\end{array}$ & 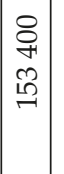 & 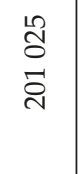 & $\begin{array}{l}8 \\
8 \\
\circ \\
\circ \\
\sim\end{array}$ & $\begin{array}{l}8 \\
8 \\
\stackrel{1}{ } \\
\infty \\
\infty\end{array}$ & $\begin{array}{l}\stackrel{8}{f} \\
\infty \\
\text { N }\end{array}$ & $\begin{array}{l}8 \\
\vdots \\
12 \\
\infty \\
\infty\end{array}$ & 1 & $\begin{array}{l}8 \\
0 \\
0 \\
0 \\
0 \\
\pm \\
-1 \\
\end{array}$ & 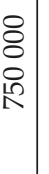 & $\begin{array}{l}\text { ڤે } \\
\hat{0} \\
\hat{\aleph} \\
\text { ते }\end{array}$ & $\begin{array}{l}8 \\
8 \\
10\end{array}$ \\
\hline & ○. & 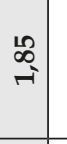 & 1 & 1 & $\begin{array}{l}5 \\
0 \\
0\end{array}$ & ô & 1 & 1 & $\begin{array}{l}5 \\
0 \\
0\end{array}$ & 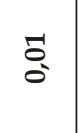 & $\begin{array}{l}5 \\
0 \\
0\end{array}$ & $\begin{array}{l}\text { ô } \\
\text { ó }\end{array}$ & $\begin{array}{l}0 \\
0 \\
0\end{array}$ & 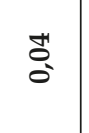 & 8 & $\begin{array}{l}-5 \\
0\end{array}$ & $\tilde{0}$ & $\underset{\sim}{\stackrel{\Delta}{-}}$ & 1 \\
\hline$\vec{\sharp}$ & 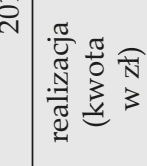 & $\begin{array}{l}5 \\
\hat{\sigma} \\
9 \\
7 \\
7 \\
7\end{array}$ & 1 & 1 & 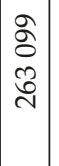 & $\begin{array}{l}\overrightarrow{1} \\
\infty \\
\infty \\
\llcorner \\
\llcorner \\
\rightarrow\end{array}$ & 1 & 1 & $\mid \begin{array}{l}\sigma \\
\tilde{\omega} \\
0 \\
\vec{\sim}\end{array}$ & 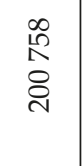 & 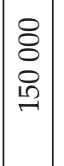 & $\begin{array}{l}\stackrel{8}{O} \\
\underset{+}{+} \\
\stackrel{9}{7}\end{array}$ & $\begin{array}{l}\hat{\infty} \\
o \\
\vec{f}\end{array}$ & $\begin{array}{l}\infty \\
o n \\
10 \\
\swarrow 2 \\
\alpha\end{array}$ & 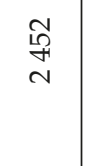 & 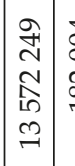 & 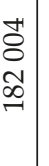 & 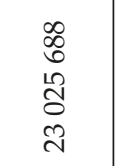 & 1 \\
\hline & 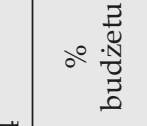 & \begin{tabular}{l}
$\infty$ \\
\hdashline \\
\hdashline
\end{tabular} & 1 & 5 & 1 & $\begin{array}{l}: \\
0 \\
0\end{array}$ & 1 & 1 & $\mid \begin{array}{l}\tilde{5} \\
0 \\
0\end{array}$ & : & $\begin{array}{l}5 \\
0 \\
0\end{array}$ & $\stackrel{0}{0}$ & $\begin{array}{l}0 \\
0 \\
0\end{array}$ & : & 1 & $\begin{array}{l}0 \\
: \\
0 \\
0\end{array}$ & 1 & \&్ & 1 \\
\hline & 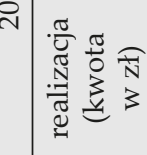 & $\begin{array}{ll}\infty & \\
0 \\
0 \\
0 \\
0 \\
1 \\
0 \\
0 \\
0\end{array}$ & 1 & $\begin{array}{l}\text { तె } \\
\infty \\
\infty \\
\infty \\
-\end{array}$ & , & 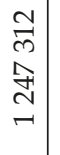 & 1 & 1 & $\mid \begin{array}{l}8 \\
o \\
o \\
\vec{n} \\
\end{array}$ & $\begin{array}{l}\text { సे } \\
\text { సे } \\
\text { సి }\end{array}$ & 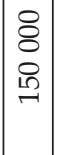 & $\begin{array}{l}\text { ڤั } \\
\text { के } \\
\text { के }\end{array}$ & 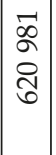 & $\begin{array}{l}\infty \\
\infty \\
\infty \\
\approx \\
\sigma\end{array}$ & 1 & 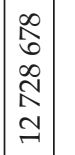 & 1 & 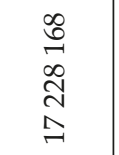 & 1 \\
\hline & 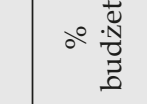 & $\begin{array}{l}\tilde{\theta} \\
- \\
-\end{array}$ & 1 & 1 & 1 & $\begin{array}{l}\infty \\
0 \\
0 \\
0\end{array}$ & 1 & 1 & \begin{tabular}{|c|}
$\tilde{\sigma}$ \\
0 \\
0
\end{tabular} & s. & $\begin{array}{l}5 \\
0 \\
0\end{array}$ & $\stackrel{\text { on }}{0}$ & $\begin{array}{l}\text { t' } \\
0 \\
0\end{array}$ & 능 & 1 & $\begin{array}{l}\text { 象 } \\
\stackrel{2}{0}\end{array}$ & 1 & $\begin{array}{l}\overrightarrow{0} \\
0 \\
0\end{array}$ & I \\
\hline & 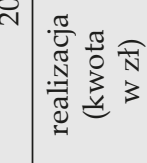 & 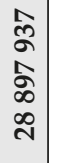 & 1 & 1 & 1 & $\begin{array}{l}8 \\
8 \\
\llcorner \\
\stackrel{2}{\$} \\
-\end{array}$ & 1 & 1 & 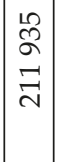 & 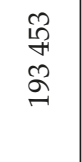 & $\begin{array}{l}8 \\
8 \\
\infty \\
\infty \\
-\end{array}$ & 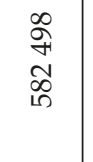 & 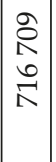 & $\begin{array}{l}\stackrel{9}{7} \\
\not \\
\stackrel{2}{\infty} \\
\infty\end{array}$ & 1 & 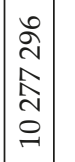 & 1 & 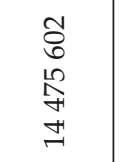 & 1 \\
\hline & 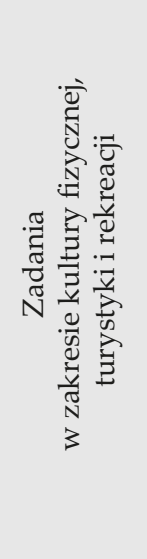 & & 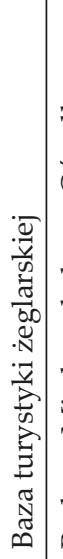 & 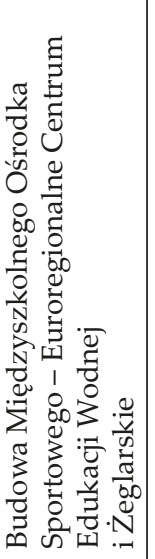 & 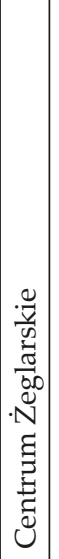 & 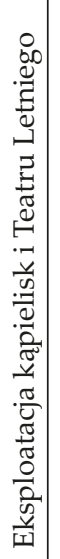 & 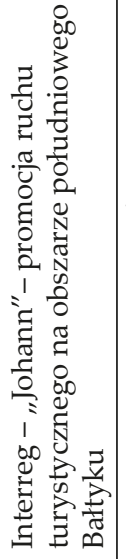 & 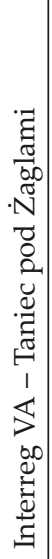 & 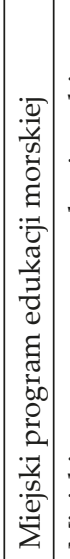 & 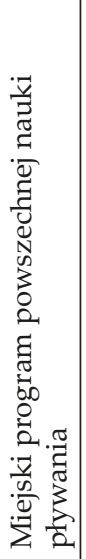 & 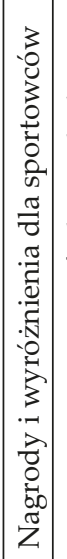 & 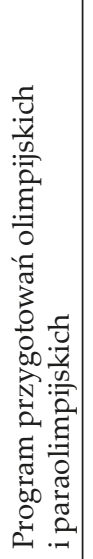 & 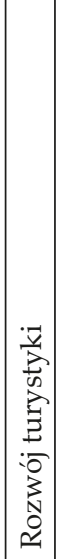 & 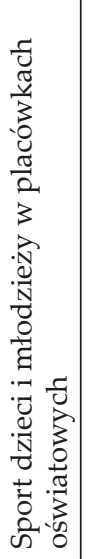 & 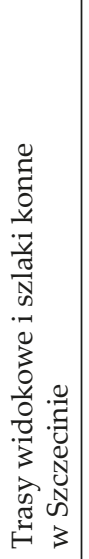 & 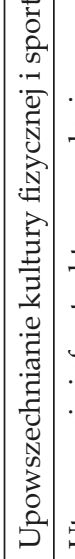 & 'a & 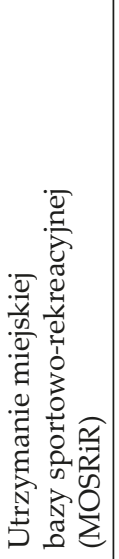 & 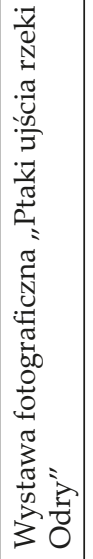 \\
\hline
\end{tabular}


4. Bulwary - kontynuowanie przebudowy i modernizacji szczecińskich bulwarów-nabrzeży Wałów Chrobrego, wyspy Grodzkiej i Łasztowni.

5. Kąpieliska - modernizowanie szczecińskich kąpielisk otwartych: Dąbie, Głębokie, Dziewoklicz.

6. Centrum Żeglarskie - kontynuowanie jego rozbudowy.

7. Mare Dambiensis - kontynuowanie inwestycji "Zakątki żeglarskie" wraz z kreacją produktu turystycznego Mare Dambiensis, który łączy aktywną turystykę wodna, żeglarską i pieszą w oparciu o potencjał jeziora Dąbie.

Inne ważne dla społeczności lokalnej i turystów projekty w przestrzeni publicznej, których realizacja pozwoli podnieść jakość życia w mieście, to:

- Teatr Letni - dalsza modernizacja amfiteatru w parku Kasprowicza,

- Miejsce Spotkań Willa Lentza - odrestaurowanie obiektu,

- Brama Portowa - odrestaurowanie obiektu,

- Teatr Współczesny - modernizacja,

- Przystanek Gruneberga - odrestaurowanie i udostępnienie Willi Gruneberga,

- plac Żołnierza Polskiego - modernizacja,

- utworzenie Centrum Kultury Technicznej przy Muzeum Techniki i Komunikacji.

Do ważnych przedsięwzięć należą także projekty budowy lub renowacji obiektów sportowo-rekreacyjnych, oczekiwanych przez mieszkańców od wielu lat, takich jak: modernizacja stadionu miejskiego, budowa aquaparku i modernizacja kortów tenisowych.

W okresie realizacji opisywanego projektu badawczego zostało zrealizowanych wiele różnorodnych inwestycji i projektów, których bezpośrednim lub pośrednim wynikiem był rozwój warunków oraz udogodnień dla rekreacji mieszkańców (i turystów), a także poprawa atrakcyjności turystycznej. W tabeli 1 przedstawiono główne zadania oraz kwoty przeznaczone na ich realizację ( $w$ tym odsetek wydatków w dziale Kultura Fizyczna, Turystyka i Rekreacja w ogólnej strukturze wydatków Urzędu Miasta).

Ponadto należy zauważyć, że stale postępuje rozbudowa sieci ścieżek rowerowych w mieście oraz systemu szczecińskiego roweru miejskiego, których finansowanie jest zapewnione głównie z puli środków przeznaczonych na transport i komunikację. Długość infrastruktury rowerowej w Szczecinie liczy ok. 115 km, $\mathrm{w}$ tym ponad $100 \mathrm{~km}$ wydzielonych dróg dla rowerów oraz blisko $15 \mathrm{~km}$ pasów ruchu dla rowerów wyznaczonych na jezdni. Od 2014 r. można korzystać z bezobsługowego systemu wypożyczalni miejskich rowerów Bike_S. System ten stanowi uzupełnienie oferty transportu publicznego, a osobom przyjezdnym ułatwia komunikację i daje możliwość bezproblemowego dotarcia do każdego punktu w mieście (Raport o stanie miasta, 2016). Bike_S początkowo liczył 32 stacje bazowe. W 2016 r. Nextbike Polska wygrał przetarg na rozbudowę systemu wypożyczalni o dodatkowe stacje, by ich liczba osiągnęła 84 .

Istotnym elementem kształtowania przestrzeni rekreacyjnej w kontekście uwzględniania potrzeb mieszkańców jest umożliwienie im wpływu na wybór realizowanych w mieście inwestycji poprzez udział w Szczecińskim Budżecie Obywatelskim (SBO). W głosowaniu na inwestycje do zrealizowania w 2018 r. oddano ok. 26 tys. ważnych głosów. Wybrano 13 projektów spośród przeszło 100 zgłoszonych. To m.in. rewitalizacja parku Żeromskiego, mural witający przyjezdnych przy wyjściu z dworca PKP od ulicy Owocowej, stworzenie "Najlepszego placu zabaw w mieście” w prawobrzeżnej części Szczecina czy instalacja „Szwajowego Ogrodu Literackiego" w parku Wolności. Pula pieniędzy w tej edycji SBO to $8 \mathrm{mln}$ zł (Radio Szczecin, 2017). Najwięcej projektów zostało wybranych o profilu sportowym, a Arkonia Szczecin wygrała w trzech kategoriach - w tym w najważniejszej, czyli projekcie ogólnomiejskim. W Lasku Arkońskim powstanie nowe boisko, a także pierwsza w województwie hala pneumatyczna $\mathrm{z}$ demontowanym dachem.

Jak wynika z tab. 1 w realizacji projektów mających zwiększyć atrakcyjność rekreacyjną i turystyczną Szczecina w badanym okresie widać wyraźny progres. Wydatki tylko w kategorii „kultura fizyczna, sport i rekreacja" zwiększyły się na przestrzeni pięciu lat właściwie dwukrotnie, wzrosła również liczba realizowanych projektów i ich zróżnicowanie. Ukończone zostały istotne inwestycje poprawiające jakość zagospodarowania rekreacyjnego miasta (które mieszkańcy uznali za niewystarczające na poprzednich etapach badań). Dodatkowo działania realizowane przez samorząd miasta Szczecin są uzupełniane projektami autorstwa innych podmiotów działających w mieście, a także wspomagane projektami realizowanymi w ramach budżetu obywatelskiego.

\section{PODSUMOWANIE}

W podsumowaniu rozważań dotyczących kształtowania przestrzeni rekreacyjnej w Szczecinie należy stwierdzić, że systematycznie rośnie liczba projektów i ich wartość, co świadczy o znaczeniu rekreacyjnego i turystycznego zagospodarowania miasta dla kompleksowo rozumianej jakości życia w mieście i jego funkcjonowania jako systemu.

Pomimo że w strukturach Urzędu Miasta Szczecin nie występuje jednostka odpowiedzialna jednocześnie za turystykę i rekreację lub turystykę, rekreację i sport, a kwestie dotyczacce tej sfery zostały przeniesione na 
zewnątrz struktur urzędu, do spółek lub innych jednostek $\mathrm{w}$ różnym stopniu powiązanych formalnie z Urzędem Miasta, to rekreacja stanowi istotny element polityki władz miasta.

Jednym z aspektów prowadzonych inwestycji w Szczecinie jest zmiana orientacji przestrzennej miasta i przywrócenie obszarom nadrzecznym ich rekreacyjnej funkcji, czego najlepszym przykładem jest powstanie bulwarów nadodrzańskich. Była to jedna z najbardziej efektownych inwestycji, a obecnie jest to jedno z najchętniej odwiedzanych miejsc w Szczecinie. Projekt „Promenada z widokiem na Odrę - przebudowa szczecińskich bulwarów" zaowocował kompleksową przebudową zagospodarowania trzech bulwarów, które w wyniku realizacji przedsięwzięcia zostały przystosowane do uprawiania turystyki wodnej, uzupełniając braki miejsc do postoju jednostek sportowych i turystycznych oraz statków białej floty. Ponadto dzięki temu projektowi dokonano modernizacji nabrzeża, inwestując w nową infrastrukturę niezbędną do obsługi jednostek pływających. Na bulwarze Piastowskim przebudowano fragment o długości 909,5 m (od połączenia z bulwarem Nadodrzańskim do Trasy Zamkowej), w wyniku czego pojawiły się nowe chodniki, ławki, kosze na śmieci oraz infrastruktura niezbędna do obsługi jednostek pływających (pachoły, oczepy, koła ratunkowe). Podłączono media (wodę i prąd) oraz stworzono możliwość odbioru ścieków. Przeprowadzono również prace konserwatorskie elewacji piaskowca. Na bulwarze Gdyńskim przebudowano ponadpółkilometrowy odcinek po stronie Urzędu Celnego (od mostu Długiego do Trasy Zamkowej). Oprócz kompleksowego zagospodarowania terenu na nabrzeżu stanął bosmanat, wyposażony w toalety, prysznice, a także pralnię. Bulwar Elbląski był remontowany w ramach tego samego projektu, ale został ukończony w 2011 r. Przebudowano tam nabrzeże i przywrócono mu funkcję użytkowa, bowiem dotąd było wyłączone z eksploatacji. Bulwar jest dziś miejscem cumowania jednostek sportowych, turystycznych oraz białej floty. Zmodernizowane nabrzeża zachęcają mieszkańców Szczecina do spędzania czasu nad Odra, a także przyciągają turystów spoza regionu, $\mathrm{w}$ tym przede wszystkim amatorów jachtingu (Szczecin, 2017). Nowy bulwar ma długość ok. 650 m. Za jego przebudowę odpowiadało konsorcjum firm Mega z Gdyni i Kowal ze Szczecina. Umowa na realizacje zadania została podpisana 27 czerwca 2016 r. Koszt inwestycji, wraz z pracami dodatkowymi ( $w$ tym m.in renowacją żurawi portowych), zamknął się w kwocie $15 \mathrm{mln}$ zł (Głos Szczeciński, 2017).

Reasumując należy stwierdzić, że intensywność, zróżnicowanie i szeroki wachlarz nowych rozwiązań inwestycyjno-modernizacyjnych dotyczących rekreacji (a także turystyki) w Szczecinie w dużej mierze odpowiada wynikom badań prowadzonych na wcze- śniejszych etapach projektu (Meyer, Gardzińska, Sawińska, 2016; Sawińska, 2016; Raport. Aktywność rekreacyjna..., 2014, 2015). Inwestycje są skierowane na te obszary i formy aktywności na świeżym powietrzu, które mieszkańcy wskazywali jako najbardziej newralgiczne w zakresie swojej aktywności w czasie wolnym oraz stanowią uzupełnienie o te elementy, których mieszkańcom brakowało (np. aqapark). Ponadto w kontekście zachowań turystów w mieście, którzy deklarowali zainteresowanie wypoczynkiem na obszarach wodnych i zielonych oraz chęć podjęcia aktywności rekreacyjnej różnego typu, można przypuszczać, że prowadzone działania i realizowane projekty pozostaja w ścisłej korelacji z tymi oczekiwaniami.

\section{PRZYPIS}

${ }^{1}$ Szerzej na ten temat pisze Meyer (2015).

\section{BIBLIOGRAFIA}

Bierwiaczonek, K. (2016). Społeczne znaczenie miejskich przestrzeni publicznych. Katowice: Wydawnictwo Uniwersytetu Śląskiego. Faracik, R., Kurek, W., Mika, M., Pawlusiński, R. (2015). „Stare” $\mathrm{i}$ „nowe” wartości w turystyce miejskiej. Zarys problematyki. W: P. Trzepacz, J. Więcław-Michniewska, A. Brzosko-Sermak, A. Kołoś (red.), Miasto w badaniach geografów (s. 121133). Karków: Instytut Geografii i Gospodarki Przestrzennej Uniwersytetu Jagiellońskiego.

Liszewski, S. (2014). Miejska przestrzeń turystyczna. Metody badań. Ewolucja i jej prawidłowości. Turyzm/Tourism, 24 (1), s. 37-47.

Meyer, B. (2015). Możliwości wykorzystania przestrzeni wodnej (i nadwodnej) w procesie konkurencji regionów miejskich, na przykładzie Szczecina. W: A. Rapacz (red.), Gospodarka turystyczna w regionie. Przedsiębiorstwo. Samorzad. Wspótpraca. Prace Naukowe Uniwersytetu Ekonomicznego we Wrocławiu, 379, s. 218226. Wrocław: Wydawnictwo Uniwersytetu Ekonomicznego we Wrocławiu, https://doi.org/10.15611/pn.2015.379.21

Meyer, B., Gardzińska, A., Sawińska, A. (2016). Miasto jako obszar aktywności turystycznej i rekreacyjnej na przykładzie Szczecina. Ekonomiczne Problemy Turystyki, 3 (35), s. 85-95.

Mokras-Grabowska, J. (2017). Nowe rekreacyjne przestrzenie miejskie w obiektach postindustrialnych i ich percepcja. Przykład kompleksu EC1 w Łodzi. Studia Periegetica, 3 (19), s. 33-45.

Raport. Aktywność rekreacyjna mieszkańców Szczecina (2014). Szczecin: Uniwersytet Szczeciński, materiały niepublikowane.

Raport. Aktywność rekreacyjna mieszkańców Szczecina (2015). Szczecin: Uniwersytet Szczeciński, materiały niepublikowane.

Sawińska, A. (2016). Miasto jako obszar aktywności turystycznej i rekreacyjnej konsumentów 50+ na przykładzie Szczecina (s. 153-165). W: W. Gierańczyk (red.), Starzenie się ludności jako wyzwanie XXI wieku. Ujęcie interdyscyplinarne. Toruń: Wyższa Szkoła Bankowa w Toruniu.

Sawińska, A. (2018). Management of senior citizens leisure time as the challenge of modern cities illustrated by the example 
of Szczecin. European Journal of Service Management, 27 (1), 3, s. $255-262$.

Śniadek, J., Zajadacz, A. (2014). Turystyka i rekreacja a jakość życia mieszkańców Leszna. Ekonomiczne Problemy Turystyki, 1 (25), s. 341-365.

Wantuch-Matla, D. (2016). Przestrzeń publiczna 2.0. Łódź: Księży Młyn Dom Wydawniczy.

Włodarczyk, B. (2011). Przestrzeń turystyczna - kilka słów o istocie pojęcia. W: M. Durydiwka, K. Duda-Gromada (red.) Przestrzeń turystyczna. Czynniki, różnorodność, zmiany (s. 15-28). Warszawa: Wema, Wydawnictwo-Poligrafia Sp. z o.o.

\section{Źródła internetowe}

Biuletyn Urzędu Miasta Szczecin (2017). Pobrane z: http://bip um.szczecin.pl/chapter_50918.asp?soid=97021E89177949248 B2D11004E96D1E7 (15.10.2017)

Eurostat. Your Key to European Statistics (2011). Report of the task force: Multidimensional measurement of the quality of life. Sponsorship Group on Measuring Progress, Well-being and Sustainable Development. Pobrane z: https://ec.europa.eu/eurostat/documents/8131721/8131772/TF3-Final-report-Qualityof-Life.pdf (16.10.2017).
Głos Szczeciński (2017). Pobrane z: http://www.gs24.pl/strefa-biznesu/wiadomosci/z-regionu/a/nowe-piekne-bulwary-w-szczecinie-zobacz-jak-wygladaja-zdjecia-wideo,12245819/ (25.11.2017).

Radio Szczecin (2017). Pobrane z: http://radioszczecin.pl/1,363117, sporo-niewaznych-glosow-w-sbo (26.11.2017).

Raport o stanie miasta (2016). Biuletyn Urzędu Miasta Szczecin. Pobrane z: http://bip.um.szczecin.pl/UMSzczecinFiles/file/ Raport_o_stanie_miasta_Szczecin2016.pdf (24.11.2017).

Strategia rozwoju Szczecina. 2025. (2011). Uchwała nr XIV/320/11 RM Szczecin z 19 grudnia 2011r., http://www.szczecin.pl/ strategia2025/.

Szczecin (2017). Pobrane z: http://www.szczecin.eu/sites/default/ files/program_szczecin_2020.pdf (10.11.2017).

Szczecińska Agencja Artystyczna (2017). Pobrane z: http://saa.pl/ dzialalnosc (15.10.2017).

Żegluga Szczecińska. Turystyka. Wydarzenia Sp. z o.o. (2017). Pobrane z: http://www.zegluga.szn.pl/pl/o-nas (15.10.2017).

Artykuł wpłynał: 26 czerwca 2018 Zaakceptowany do druku: 11 grudnia 2018 